\title{
Growth and development of cows of different levels of productivity in breeding farms of the Udmurt republic
}

\author{
Ekaterina Martynova and Valentina Yakimova* \\ Izhevsk State Agricultural Academy, 426069 Izhevsk, Russia
}

\begin{abstract}
The paper considers the impact of the growth intensity of black-and-white cows on subsequent dairy productivity. The main growth indicators of cows of different productivity levels are calculated on the basis of breeding and accounting documents from the birth to the first fruitful insemination: absolute, average daily and relative growth. The calculated indicators made it possible to study the growth intensity of highly productive cows of different productivity levels and to draw the corresponding conclusions. It was found that intensive rearing of young black-and-white cows positively affects their subsequent dairy productivity.
\end{abstract}

\section{Introduction}

The indicators of animal growth and development most accurately characterize their biological features. Body weight is one of the indicators of individual development of an animal, which can be taken into account in postembryonic life at the earliest age and, according to many scientists, has quite a close relation with subsequent productivity [1-3].

The study and knowledge of the patterns of individual growth and development allows obtaining and rearing healthy heifer replacement capable of absorbing a significant amount of various fodders with further early physiological and economic maturity and capable of producing a large amount of milk [4-8].

Many scientists established the relation between the level of dairy productivity and rearing intensity. Thus, according to the scientists of the North-Western Research Institute of Dairy and Grassland Farming, the Holstein first-calf heifers of black-and-white breed with the milk yield from $10000 \mathrm{~kg}$ and significantly exceeded the average daily gains in all age periods of less productive animals by $16-50 \mathrm{~g}$ [9].

\section{Purpose of the study}

To study the growth intensity of highly productive cows of different productivity levels.

\section{Materials and methods}

The study was carried out in stud farms that raise blackand-white cattle of the Udmurt Republic. The study included the group of cows displaced from 2012 to 2017 with completed lactation. All studied cow population
(3660 heads) was conditionally divided into 3 groups by the highest lactation within the milk yield. The selection into groups was carried out on the basis of biometric data processing using the mean value $(\bar{X})$ and the mean square deviation $(\sigma)$ for the highest lactation. The boundary of selection to the group of highly productive cows was $\bar{X}+1 \sigma$, to the group of record cows $-\bar{X}+2 \sigma$, the remaining cows belonged to the production group.

The absolute gain (A) was defined by the formula:

$$
\mathrm{A}=\mathrm{W}_{\mathrm{t}}-\mathrm{W}_{\mathrm{o}} \text {, }
$$

where $\mathrm{W}_{\mathrm{t}}$ - body weight at the end of the period; $\mathrm{W}_{\mathrm{o}}-$ body weight at the beginning of the period.

The average daily gain (D) was defined by the formula:

$$
\mathrm{D}=\mathrm{A} / \mathrm{t} \text {, }
$$

where $\mathrm{A}$ - absolute gain; $\mathrm{t}$ - length of the period.

The relative gain $(\mathrm{K})$ was defined by the formula: $\mathrm{K}=\left(\left(\mathrm{W}_{\mathrm{t}}-\mathrm{W}_{\mathrm{o}}\right) / 0.5 \times\left(\mathrm{W}_{\mathrm{t}}+\mathrm{W}_{\mathrm{o}}\right)\right) \times 100 \%$.

The biometric processing of results was carried out in Microsoft Excel.

\section{Results and discussion}

The dynamics of body weight of cows of different productivity levels by growth periods from the birth to the $1^{\text {st }}$ fruitful insemination is shown in Table 1.

The difference in body weight of cows of different productivity levels at birth was insignificant and made $0.97-0.99 \mathrm{~kg}$, while the body weight at birth with the largest percentage of variability made $11.29-12.88 \%$. Among the record cows, there were 4.8 and $10.0 \%$ more cows with the body weight at birth making more than $35 \mathrm{~kg}$ than among other cows (Fig. 1).

* Corresponding author: valentine.yaki@yandex.ru 
Table 1. Dynamics of body weight of black-and-white cows of different productivity levels, $\mathrm{kg}$

\begin{tabular}{|c|c|c|c|c|c|c|}
\hline \multirow{2}{*}{ Age } & \multicolumn{2}{|c|}{ Record cows } & \multicolumn{2}{|c|}{ Highly productive cows } & \multicolumn{2}{|c|}{ Production group } \\
\hline & $\mathrm{X} \pm \mathrm{m}_{\mathrm{x}}$ & $\mathrm{Cv}, \%$ & $\mathrm{X} \pm \mathrm{m}_{\mathrm{x}}$ & $\mathrm{Cv}, \%$ & $\mathrm{X} \pm \mathrm{m}_{\mathrm{x}}$ & $\mathrm{Cv}, \%$ \\
\hline At birth & $33.21 \pm 0.53$ & 12.88 & $32.24 \pm 0.26$ & 12.7 & $32.22 \pm 0.11$ & 11.29 \\
\hline 6 & $166.49 \pm 1.84$ & 9.28 & $168.41 \pm 1.04$ & 10.1 & $168.14 \pm 0.45$ & 9.49 \\
\hline 10 & $258.97 \pm 2.72$ & 8.78 & $261.65 \pm 1.52$ & 9.45 & $259.64 \pm 0.67$ & 9.16 \\
\hline 12 & $300.61 \pm 2.86$ & 7.91 & $305.25 \pm 1.69$ & 9.07 & $302.97 \pm 0.74$ & 8.74 \\
\hline 18 & $416.07 \pm 3.31$ & 6.71 & $420.3 \pm 2.03$ & 7.97 & $418.19 \pm 0.9$ & 7.92 \\
\hline At first fruitful insemination & $405.69 \pm 3.75$ & 7.79 & $410.03 \pm 2.02$ & 8.19 & $405.05 \pm 0.94$ & 8.4 \\
\hline
\end{tabular}

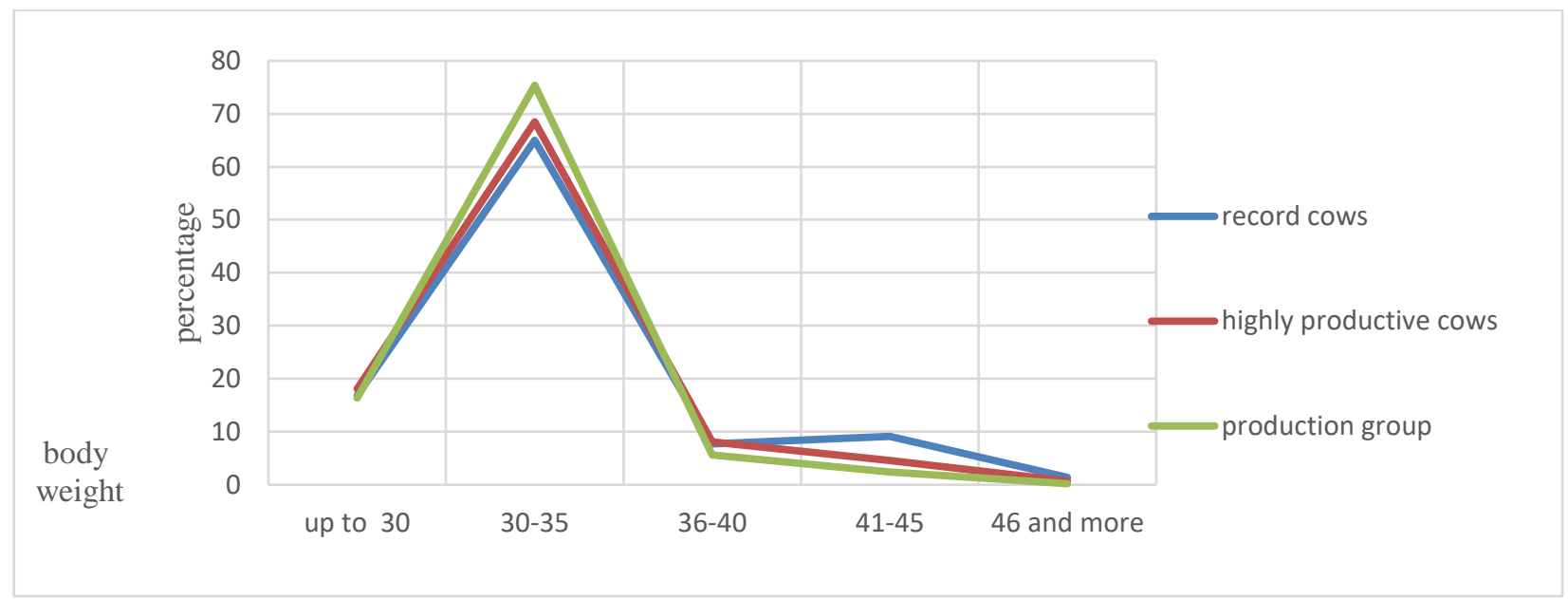

Fig. 1. Body weight at birth of cows of different productivity levels

At 6 months the body weight of highly productive cows was more than the body weight of record cows and the production group by 1.92 and $0.27 \mathrm{~kg}$ respectively. At the same time 6 months the body weight of 170-189 kg was typical for $31.5 \%$ of record cows and $33.9 \%$ of highly productive cows, and only $26.3 \%$ of the production group (Fig. 2).

This trend continued in subsequent age periods. Thus, the body weight of highly productive cows at 10 months was 2.68 and $2.01 \mathrm{~kg}$ more than that of record cows and cows of the production group respectively. On average the body weight of cows of all groups satisfied the breed standard, but among cows of the production group the body weight of $38.6 \%$ of cows was less than $250 \mathrm{~kg}$, which is $7.1 \%$ more than in other groups (Fig. 3).

At 12 months, the average body weight of cows of all groups was at the level of the 2010 standard for Holstein breed (300-305 kg), but varied within groups from 200 to $390 \mathrm{~kg}$.

Thus, the minimum body weight $(250 \mathrm{~kg})$ of record cows at 12 months was among $1.4 \%$ of cows, highly productive cows $-2.2 \%$, cows of the production group $2.8 \%$ (Fig. 4).

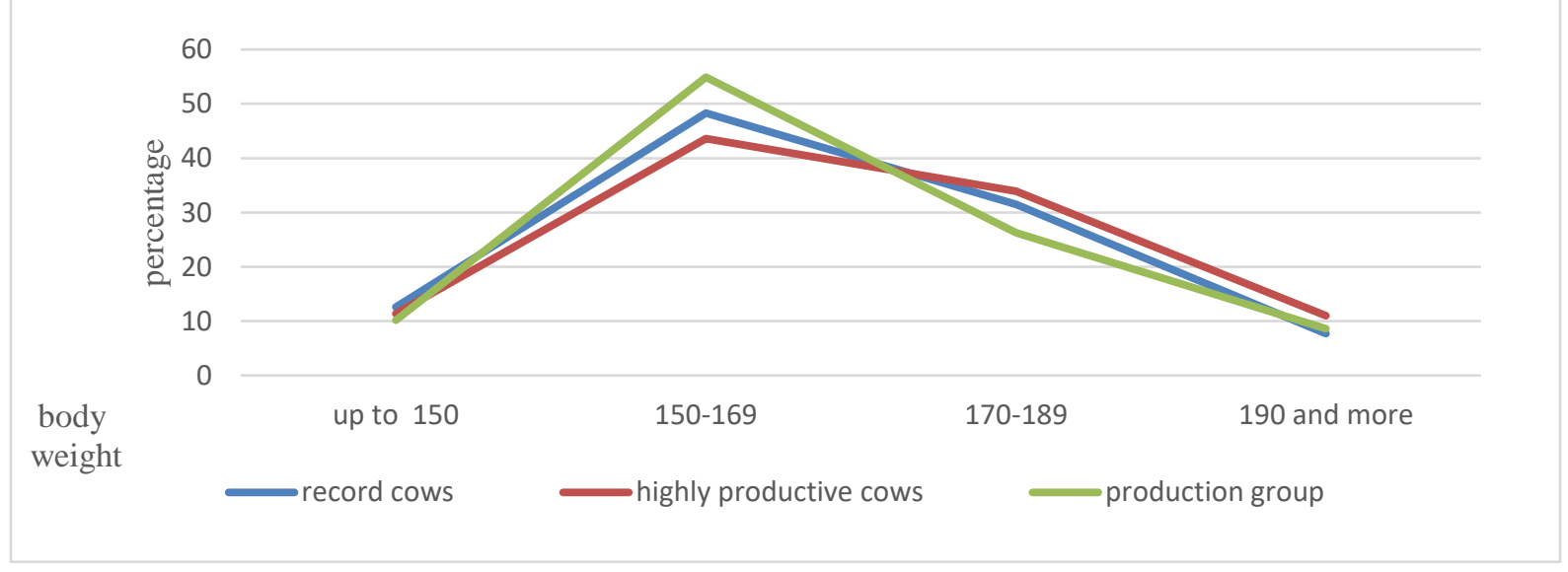

Fig. 2. Dynamics of body weight at the age of 6 months of cows of different groups 


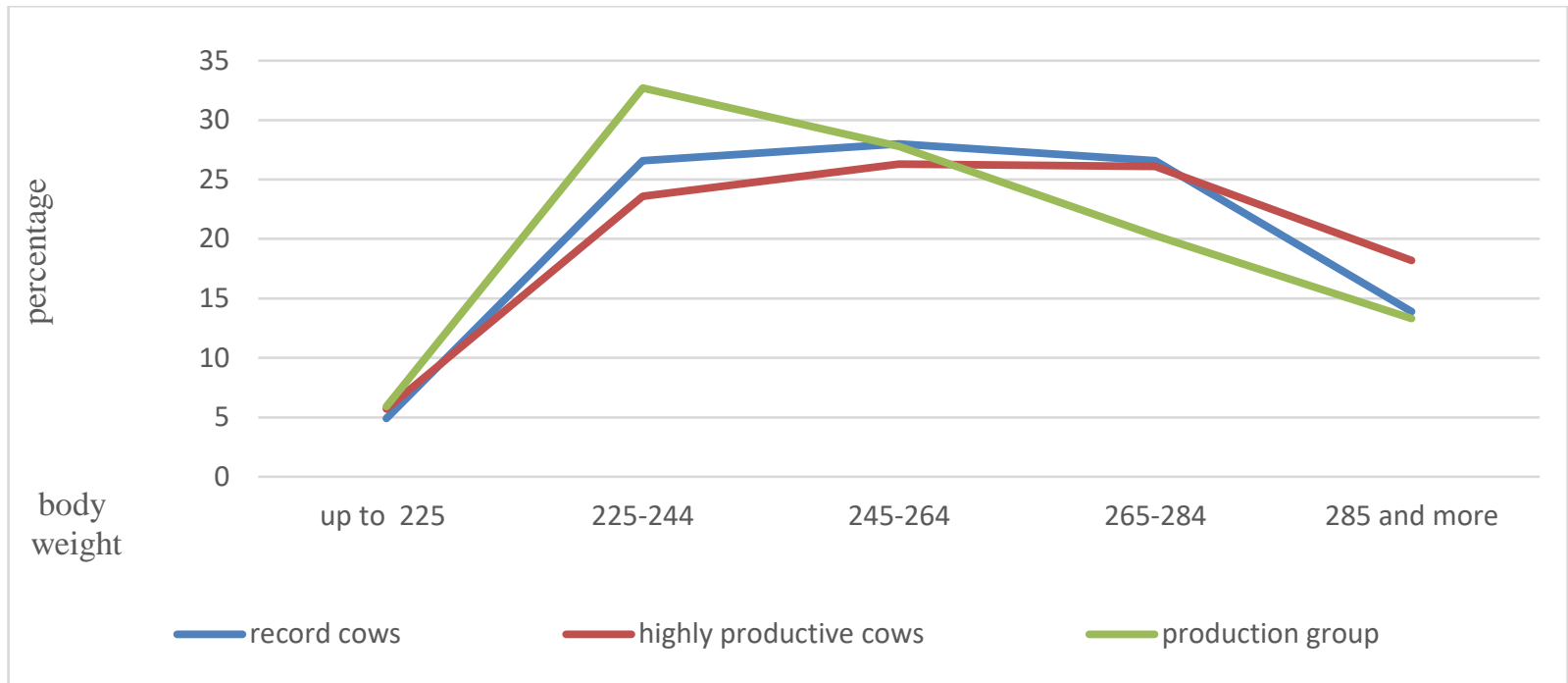

Fig. 3. Dynamics of body weight at the age of 10 months of cows of different groups

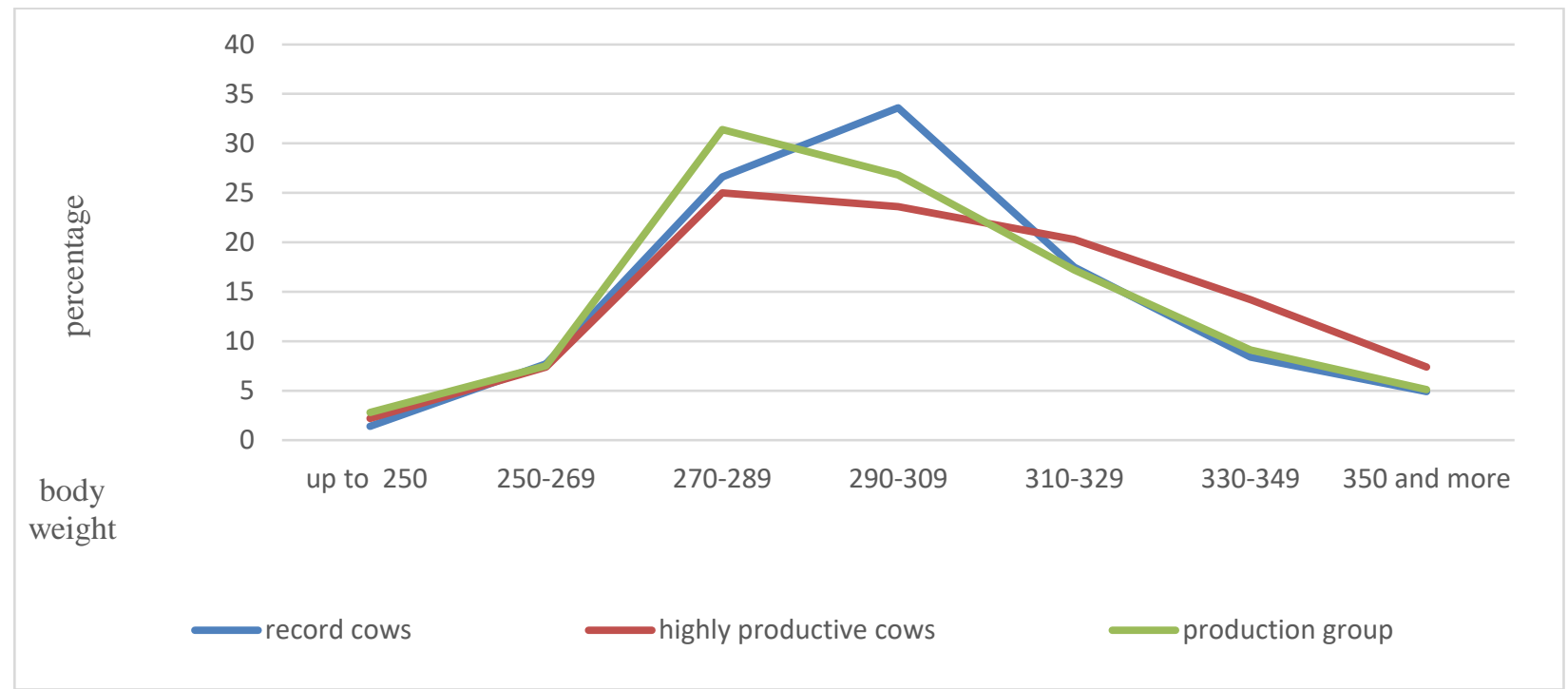

Fig. 4. Dynamics of body weight at the age of 12 months of cows of different groups

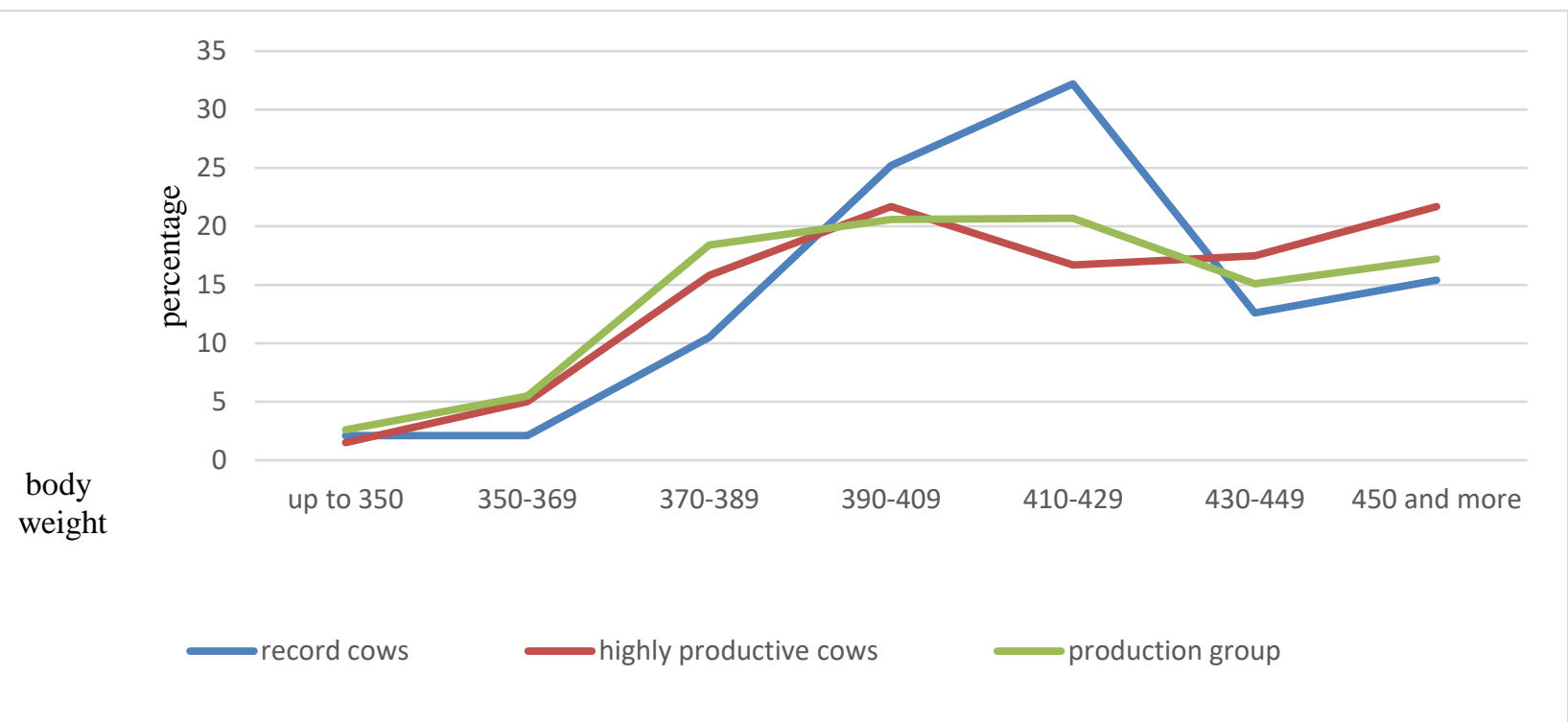

Fig. 5. Dynamics of body weight at the age of 18 months of cows of different groups 
At the same time the largest percentage of record cows had the optimal body weight at 12 months $-290-320 \mathrm{~kg}$.

The highest body weight at the age of 18 months was typical for highly productive cows $-420.3 \mathrm{~kg}$ and exceeded the body weight of record cows by $4.2 \mathrm{~kg}$ and the cows of the production group by $2.1 \mathrm{~kg}$.

At 18 months, the body weight of $57.4 \%$ of record cows made $390-430 \mathrm{~kg}$, which is $19-10 \%$ more than among the cows of other groups (Fig. 5), with the least variability of the feature.

In all age periods, the difference in the body weight of cows was statistically unreliable and ranged from 0.27 to $4.98 \mathrm{~kg}$.

The level of body weight gain also characterizes the growing capacity of cows. It is determined by the calculation of the absolute gain, which represents the dynamics of body weight increase, the relative gain, which shows the growth rate in percentage ratio, as well as the average daily gain, which shows changes of body weight during the day (Table 2).

Table 2. Growth rate of cows of different productivity levels

\begin{tabular}{|c|c|c|c|c|c|c|}
\hline \multirow{2}{*}{$\begin{array}{c}\text { Age } \\
\text { period, } \\
\text { month }\end{array}$} & Record cows & $\begin{array}{c}\text { Highly-productive } \\
\text { cows }\end{array}$ & \multicolumn{2}{c|}{$\begin{array}{c}\text { Production } \\
\text { group }\end{array}$} \\
\cline { 2 - 8 } & $\mathrm{X} \pm \mathrm{m}$ & $\begin{array}{c}\mathrm{Cv}, \\
\%\end{array}$ & $\mathrm{X} \pm \mathrm{m}$ & $\mathrm{Cv}, \%$ & $\mathrm{X} \pm \mathrm{m}$ & $\begin{array}{c}\mathrm{Cv} \\
\%\end{array}$ \\
\hline \multicolumn{7}{|c|}{ Absolute gain } \\
\hline $0-6$ & $133.10 \pm 1.9$ & 11.8 & $136.2 \pm 1.0$ & 12.5 & $135.9 \pm 0.5$ & 11.8 \\
\hline $6-12$ & $134.1 \pm 2.5$ & 13.2 & $136.8 \pm 1.3$ & 15.1 & $134.8 \pm 0.6$ & 15.1 \\
\hline $12-18$ & $115.5 \pm 2.3$ & 17.0 & $115.0 \pm 1.3$ & 19.1 & $115.0 \pm 0.7$ & 21.9 \\
\hline $0-18$ & $382.8 \pm 3.2$ & 7.1 & $388.1 \pm 2.0$ & 8.5 & $385.8 \pm 0.9$ & 8.8 \\
\hline \multicolumn{7}{|c|}{ Average daily gain } \\
\hline $0-6$ & $740.5 \pm 9.0$ & 11.8 & $756.9 \pm 5.8$ & 12.5 & $755.2 \pm 2.5$ & 11.7 \\
\hline $6-12$ & $745.1 \pm 9.4$ & 13.1 & $760.3 \pm 7.0$ & 15.1 & $749.0 \pm 3.1$ & 15.1 \\
\hline $12-18$ & $641.4 \pm 15.9$ & 17.0 & $639.1 \pm 7.4$ & 19.1 & $639.0 \pm 3.8$ & 21.9 \\
\hline $0-18$ & $709.0 \pm 11.5$ & 7.1 & $718.7 \pm 3.7$ & 8.5 & $714.4 \pm 1.7$ & 8.8 \\
\hline \multicolumn{7}{|c|}{ Relative gain } \\
\hline $0-6$ & $133.6 \pm 1.0$ & 6.5 & $135.6 \pm 0.5$ & 6.3 & $135.4 \pm 0.3$ & 5.6 \\
\hline $6-12$ & $57.5 \pm 0.7$ & 11.1 & $57.7 \pm 0.4$ & 12.4 & $57.2 \pm 0.2$ & 12.3 \\
\hline $12-18$ & $32.3 \pm 0.6$ & 16.9 & $31.8 \pm 0.4$ & 18.8 & $31.9 \pm 0.2$ & 25.0 \\
\hline $0-18$ & $170.4 \pm 0.4$ & 2.3 & $172.0 \pm 0.7$ & 7.2 & $171.1 \pm 0.1$ & 4.8 \\
\hline
\end{tabular}

The analysis of the absolute gain showed that the largest gain was in the period from birth to 18 months in the group of highly productive cows $-388.14 \mathrm{~kg}$, which is 5.91 and $2.35 \mathrm{~kg}$ more than of the record cows and the cows of the production group respectively.

The analysis of the average daily gain showed that the largest gain was in the period from 6 to 12 months in the group of highly productive cows $-760.3 \mathrm{~g}$, which is more than the group of record cows and the production group by 15.2 and $11.3 \mathrm{~g}$ respectively.

The lowest gain was in the production group between 12 and 18 months $-639.0 \mathrm{~g}$, which is 2.42 and $0.11 \mathrm{~g}$ less than in the group of record cows and highly productive cows respectively.

The analysis of the relative gain showed that it naturally decreases with age. The highest relative gain was naturally between birth and 6 months and made 133.6-135.6\%. The lowest relative gain was observed between 12 and 18 months and made $31.8-32.3 \%$.

The relative gain between birth and 18 months is slightly higher in the highly production group -172.02
$\%$, which is more than in the record cow group and the production group by 1.6 and $0.92 \%$ respectively.

The correlation relationship of the body weight of cows of different productivity level with the milk yield (Table 3) shows that in the group of record cows there is weak positive relation between the body weight in all age periods and the milk yield over the first lactation.

The correlation coefficient varied from 0.09 to 0.18 . All groups of cows are characterized by weak positive relation between the body weight at 18 months and the milk yield over the first lactation $-0.14-0.18$.

Table 3. Correlation relationship of body weight and milk yield over 305 days of the first lactation of cows of different productivity levels

\begin{tabular}{|c|c|c|c|c|c|}
\hline Milk yield & \multicolumn{5}{|c|}{ Body weight, kg } \\
\cline { 2 - 6 } $\begin{array}{c}\text { over 305 } \\
\text { days of the } \\
\text { first } \\
\text { lactation: }\end{array}$ & $\begin{array}{c}\text { At } \\
\text { birth }\end{array}$ & $\begin{array}{c}\text { at 6 } \\
\text { months }\end{array}$ & $\begin{array}{c}\text { at } 10 \\
\text { months }\end{array}$ & $\begin{array}{c}\text { at } 12 \\
\text { months }\end{array}$ & $\begin{array}{c}\text { at } 18 \\
\text { months }\end{array}$ \\
\hline Record cows & 0.09 & 0.10 & 0.14 & 0.11 & 0.18 \\
\hline $\begin{array}{c}\text { Highly } \\
\text { productive } \\
\text { cows }\end{array}$ & 0.06 & 0.06 & 0.09 & 0.10 & 0.18 \\
\hline $\begin{array}{c}\text { production } \\
\text { group }\end{array}$ & 0.03 & -0.02 & 0.02 & 0.04 & 0.14 \\
\hline
\end{tabular}

There is the positive relation of the body weight at birth with the body weight during the main age periods from 0.15 to 0.28 .

\section{Conclusion}

The study revealed that intensive young-stock breeding of black-and-white cows has a positive impact on their subsequent dairy productivity. There is a positive relation of the milk yield over 305 days of the $1^{\text {st }}$ lactation with the body weight of cows at the age of 6 , $10,12,18$ months and at birth $(\mathrm{r}=0.10 ; 0.14 ; 0,11 ; 0,18$; 0.09 , respectively).

\section{References}

1. L.N. Bakeeva, S.V. Karamaev, A.S. Karamaeva, News Samara State Agricult. Acad., 74-77 (2015)

2. O.N. Burgomistrova, N. I. Abramova, O.L. Hromov, Genet. and animal breeding, 57-63 (2018)

3. E.N. Martynova, O.G. Pushkarev, Mater. Int. sci. scient. Conf. young scientists and specialists "Outlook for the development of Russian regions in the XXI century”, 139-143 (2002)

4. D.S. Vilver, Mater. Int. sci.-tech. Conf. "Biotechnology-agro-industrial complex of Russia", 25-30 (2017)

5. E.N. Martynova, K.V. Ustinova, Collection of scientific works "Actual problems of intensive development of animal husbandry”, 307-314 (2016)

6. A.V. Maklahov, N.I. Abramova, O.L. Hromova, V.A. Makurina, Main livestock, 16-21 (2016)

7. D. Drew, Livestock Farmg, 38-39 (1983) 
8. G.M. Haworth, W.P. Trantez, J.N. Chuck, Z. Cheng, D.C. Walthes, The Veterinary Record, 643-647 (2008)
9. A.A. Sermyagin, A.A. Filipenchenko, A.N. Ermilov, A.N. Yanchukov, Far East Agrarian Herald, 194-202 (2018) 